\title{
FORMULASI DAN EVALUASI SEDIAAN GEL HAND SANITIZER DENGAN BAHAN DASAR EKSTRAK BIJI ALPUKAT
}

\author{
Yeni Agustin ${ }^{1}$, Septi Wulandari ${ }^{1}$ \\ ${ }^{1}$ Program Studi S1 Farmasi STIK Siti Khadijah Palembang
}

\begin{abstract}
Formulation and Evaluation of Gel Hand Sanitizer With Basic Ingredients Of Avocado Seed Extract. During the Covid-19 pandemic, people were required to wash or clean their hands more often using soap or other hand sanitizer preparations. With the hope of being able to avoid or eliminate various bacteria, germs or dirt in the hand area, both before and after daily activities. One form of hand sanitizer that functions as an antiseptic is a hand sanitizer gel. Generally, the active ingredient that is widely used is triclosan. It is hoped that there will be other alternative active ingredients that are more effective and environmentally friendly, including avocado seed extract. This research is in the form of experimental research, namely the gel formulation hand sanitizer avocado seed extract with various alcohol concentrations of F1 0\%, F2 10\%, F3 20\%, F4 $60 \%$ including (organoleptic, homogeneity, $\mathrm{pH}$, dispersive power, consistency and viscosity). And continued with the inhibition zone test against E. Coli bacteria. The hand sanitizer preparation based on third formulation (F3) avocado seed extract with an alcohol content of $96 \%$ as much as $20 \% \mathrm{w} / \mathrm{v}$ has the largest inhibition zone diameter value against $\mathrm{E}$. coli bacteria and has better physical characteristics of the hand sanitizer preparation.
\end{abstract}

Keywords: Extract, Avocado Seed, Hand Sanitizer

\begin{abstract}
Abstrak: Formulasi Dan Evaluasi Sediaan Gel Hand Sanitizer Dengan Bahan Dasar Ekstrak Biji Alpukat. Pada masa pandemi Covid-19, masyarakat dituntut untuk lebih sering mencuci atau membersihkan tangan baik dengan menggunakan sabun ataupun sediaan pembersih tangan lainnya.Dengan harapan mampu menghindarkan atau menghilangkan berbagai bakteri, kuman ataupun kotoran yang ada pada area tangan, baik sebelum maupun setelah beraktivitas dalam keseharian. Salah satu bentuk sediaan pembersih tangan yang berfungsi sebagai antiseptik adalah gel hand sanitizer. Umumnya bahan aktif yang banyak digunakan adalah triklosan. Diharapkan ada bahan aktif alternatif lainnya yang lebih efektif dan ramah lingkungan diantaranya ekstrak biji alpukat. Penelitian ini berupa penelitian eksperimental yaitu pada formula gel hand sanitizer ekstrak biji alpukat dengan berbagai konsentrasi alkohol F1 0\%, F2 10\%, F3 20\%, F4 60\% meliputi (organoleptik, homogenitas, $\mathrm{pH}$, daya dispersif, konsistensi dan viskositas) dan dilanjutkan dengan uji zona hambat terhadap bakteri E. Coli. Sediaan hand sanitizer dengan bahan dasar ekstrak biji buah alpukat formulasi 3 (F3) dengan kandungan alkohol $96 \%$ sebanyak $20 \%$ b/v mempunyai nilai diameter zona hambat yang paling besar terhadap bakteri $E$. coli dan memiliki karakteristik fisik sediaan hand sanitizer yg lebih baik.
\end{abstract}

Kata Kunci: Ekstrak, Biji Alpukat, Hand Sanitizer

\section{PENDAHULUAN}

Alpukat (Persea americana Mill.)

merupakan tanaman yang dapat tumbuh subur di daerah tropis seperti Indonesia. Sebagian besar masyarakat memanfaatkan alpukat pada buahnya saja sedangkan bagian lain seperti biji kurang dimanfaatkan. Biji alpukat memiliki kandungan senyawa antioksidan potensial, seperti senyawa fenolik, yang dapat dimanfaatkan untuk konsumsi manusia (Anggraeny, 2017). 
Biji alpukat juga dimanfaatkan di Nigeria sebagai obat tradisional dalam mengobati orang yang memiiliki tekanan darah tinggi (Ozolua dkk., 2009). Diketahui biji alpukat mengandung senyawa fitosterol, triterpen, asam lemak, asam furanoik, dimer flavonol, proantosianidin, dan asam absisat. Beberapa senyawa tersebut telah terbukti memiliki aktivitas antifungi dan efek larvasidal (Leite et a.l, 2009). Menurut hasil penelitian Suhendra dkk. (2016), ekstrak biji alpukat berefek menurunkan kadar kolesterol total pada tikus Wistar. Rerata kadar kolesterol total tikus Wistar setelah diberikan 125 $\mathrm{mg} / \mathrm{kg}$ dan $250 \mathrm{mg} / \mathrm{kg}$ ekstrak biji alpukat menurun sebesar $18,1 \%$ dan $31,2 \%$. Berdasarkan penelitian sebelumnya juga menyatakan bahwa ekstrak biji alpukat (Persea Americana Mill.) berpotensi sebagai antimikroba terhadap mikroba patogen secara in vitro (Riadi, 2014). Dengan begitu biji alpukat dapat dimanfaatkan sebagai salah satu komponen bahan dasar dalam pembuatan pembersih tangan berupa gel.

Sediaan pembersih tangan berupa gel biasanya menggunakan alkohol sebagai antiseptik atau desinfektan seperti etanol (60-90\%), isopropil alkohol (70-90\%), dan npropanolol (60-70\%), yang telah terbukti efektif dalam membunuh bakteri. Kandungan bahan antibakterial lainnya yang ada pada hand sanitizer adalah triklosan, gliserol atau agen antimikroba lainnya (WHO, 2009). Triklosan merupakan suatu bahan kimia anti bakteri yang banyak digunakan dalam berbagai produk salah satunya adalah pembersih tangan atau hand sanitizer.

\section{METODE}

Jenis penelitian ini adalah penelitian eksperimental yang dilakukan di Laboratorium Kimia Farmasi STIK Siti Khadijah dan Laboratorium Mikrobiologi
Fakultas Kedokteran Universitas Sriwijaya. Pelaksanaannya pada bulan Oktober 2018 sampai dengan Desember 2018.

\section{Bahan}

Bahan yang digunakan adalah biji alpukat, etanol 96\%, kertas saring, aquades, gliserol, propilen glikol, $\mathrm{Na}$ CMC, media muller hinton agar, bakteri E.coli, $\mathrm{NaCl} 0,9 \%$, hand sanitizer dipasaran.

\section{Alat}

Alat yang digunakan timbangan, erlenmeyer, gelas piala, gelas ukur, mistar, cawan penguap, cawan petri, spatula, pengaduk kaca, gelas arloji, oven, mikropipet, tabung reaksi, sentrifuge, Viscometer Brookfield, $\mathrm{pH}$ meter, hot plate, jarum ose, lumpang.

\section{Pembuatan Ekstrak}

Biji alpukat dikeringkan dengan cara dirajang dan diangin-anginkan terlindung dari cahaya matahari langsung. Biji alpukat yang telah kering dihaluskan diayak menggunakan ayakan mesh 40 (serbuk agak kasar) (Depkes, 2017). Selanjutnya serbuk simplisia diekstraksi menggunakan pelarut etanol $96 \%$ dengan metode maserasi.

\section{Pembuatan Formulasi Gel Hand Sanitizer Ekstrak Biji Alpukat}

Sediaan gel yang dibuat berdasarkan formulasi standar gel yang dimodifikasi, bahan basis gel yang akan digunakan : Na-CMC, propilenglikol. Gel pembersih tangan dibuat dengan cara $\mathrm{Na}-\mathrm{CMC}$ diaduk dengan air panas sampai mengembang. Ekstrak biji alpukat ditambah etanol $96 \%$ dan propilenglikol diaduk sampai homogen. Lalu digerus dengan Na-CMC tadi yang telah dikembangkan. Selanjutnya ditambahkan sisa air, diaduk sampai homogen dan terbentuk sediaan gel. 
Tabel 1. Formula Gel Hand Sanitizer Ekstrak Biji Alpukat

\begin{tabular}{cccccc}
\hline \multirow{2}{*}{ No } & \multirow{2}{*}{ Bahan } & \multicolumn{5}{c}{ Formula (\%o/v) } \\
\cline { 3 - 6 } & & F1 & F2 & F3 & F4 \\
\hline 1 & Eks. biji alpukat & 2 & 2 & 2 & 2 \\
2 & CMC & 1 & 1 & 1 & 1 \\
3 & Gliserol & 10 & 10 & 10 & 10 \\
4 & Propilenglikol & 5 & 5 & 5 & 5 \\
5 & Etanol 96\% & 0 & 10 & 20 & 40 \\
6 & Aqua dest & ad 100 & ad 100 & $\operatorname{ad~} 100$ & ad 100 \\
\hline
\end{tabular}

\section{Evaluasi Sediaan Gel}

\section{A. Uji Organoleptis}

Sediaan gel dilihat secara fisik meliputi bentuk, warna, dan bau dari gel yang dibuat. Gel merupakan sediaan jernih dengan konsistensi setengah padat (Ansel, 2011)

\section{B. Uji Homogenitas}

Pengujian homogenitas dilakukan dengan mengoleskan sediaan gel yang akan diuji pada sekeping kaca atau bahan lain yang cocok, sediaan gel harus menunjukkan susunan yang homogen dan tidak menunjukkan butiran kasar.

\section{Uji Daya Sebar}

Sebanyak $0,5 \mathrm{~g}$ sampel gel diletakkan di atas kaca, kaca lainnya diletakkan di atasnya dan dibiarkan selama 1 menit. Diameter sebar gel diukur.Di atas kaca, ditambahkan $150 \mathrm{~g}$ beban tambahan dan didiamkan selama 1 menit lalu diukur diameter yang konstan.Daya sebar 5-7 cm menunjukkan konsistensi semisolid yang sangat nyaman dalam penggunaan (Garg, 2002).

\section{Uji Derajat Keasaman (pH)}

Penentuan $\mathrm{pH}$ sediaan dilakukan dengan menggunakan $\mathrm{pH}$ universal yang dicelupkan ke dalam sampel gel yang telah diencerkan tercelup dengan sempurna, $\mathrm{pH}$ universal tersebut dilihat perubahan warnanya dan dicocokkan dengan standar $\mathrm{pH}$ universal.pH sediaan topikal yaitu 4-8.

\section{E. Uji Konsistensi}

Dilakukan dengan mengamati perubahan konsistensi dari sediaan gel yang dibuat apakah terjadi pemisahan antara bahan pembentuk gel dengan pembawanya yaitu air.Pengujian konsistensi menggunakan pengujian centrifugal test di mana sampel gel disentrifugasi pada kecepatan $3800 \mathrm{rpm}$ selama 5 jam kemudian diamati perubahan fisik sediaan gel.

\section{F. Uji Viskositas}

Sebanyak 100 gram gel dimasukkan ke dalam pot (wadah uji khusus viscometerBrookfield). Viskositas gel diukur dengan Viscometer Brookfield yang dilengkapidengan spindle no. 6 pada kecepatan $20 \mathrm{rpm}$ (putaran per menit) kemudian data yang diperoleh dicatat. Pengujian dilakukan sebanyak tiga kali pengulangan.

\section{Uji Antibakteri Gel Hand Sanitizer Ekstrak Biji Alpukat terhadap Bakteri E.coli. \\ Pengujian daya hambat bakteri} dilakukan terhadap formula gel pembersih tangan ekstrak biji alpukat dengan variasi konsentrasi alkohol yaitu F1 0\%, F2 10\%, F3 20\%, F4 40\%, (kontrol negatif) dan F5 Gel Hand sanitizer di pasaran(kontrol positif) dengan menggunakan metode disc diffusion (Test Kirby-Bauer).Kertas cakram steril berukuran $6 \mathrm{~mm}$ direndam selama \pm 15 menit kedalam sediaan gel. Kertas cakram tersebut kemudian ditempatkan di atas permukaan media sesuai dengan posisi yang diinginkan dalam penelitian ini sediaan gel hand sanitizer ekstrak biji alpukat variasi konsentrasi alkohol. Kemudian dilanjutkan dengan proses inkubasi pada suhu $37^{\circ} \mathrm{C}$ selama 24 jam. Diamati zona hambat yang terbentuk yang diinterpretasikan terdapat daerah bening di sekitar atau 
sekeliling kertas cakram yang menunjukkan adanya zona hambat terhadap bakteri.

\section{HASIL}

Biji buah alpukat yang didapat dibersihkan dari kulitnya lalu dicuci hingga bersih.Kemudian biji tersebut diiris tipis-tipis agar lebih mudah dikeringkan. Setelah didapatkan biji buah alpukat yang telah kering, dihaluskan dan selanjutnya dilakukan proses maserasi. Dimana serbuk kering biji buah alpukat direndam dengan menggunakan pelarut etanol $96 \%$ selama 3 × 24 jam dengan sesekali dikocok atau diaduk.

Hasil dari perendaman disaring dengan menggunakan kerta saring, sehingga didapatkan ekstrak cair biji buah alpukat.Dilanjutkan ke tahap selanjutnya agar didapatkan ekstrak kental biji buah alpukat. Sebanyak 1200 gram simplisia kering serbuk biji buah alpukat diperoleh 50,68 gram ekstrak kental atau $4,2 \% \mathrm{~b} / \mathrm{b}$. Ekstrak kental yang didapat berwarna coklat gelap yang berupa pasta kental dan bagian atas ekstrak berupa cairan kental (seperti minyak).

\section{Gambar 1. Ekstrak kental biji buah alpukat}

Setelah didapat ekstrak kental dari sampel biji buah alpukat dilanjutkan ke pembuatan sediaan hand sanitizer atau gel pembersih tangan. Basis gel yang digunakan terdiri dari: CMC, gliserin, propilenglikol, etanol $96 \%$ dan aqua dest. Sediaan hand sanitizer dibuat dengan 4 (empat) formulasi dengan variasi jumlah etanol yang ditambahkan yakni: $0 \%, 10 \%, 20 \%$ dan $40 \%$. Didapatkan sediaan hand sanitizer yang berwarna kuning kecoklatan dan agak kental dengan aroma yang enak dari biji buah alpukat. Dan sebagai pembanding atau kontrol positif digunakan gel hand sanitizer yang sudah beredar dipasaran.

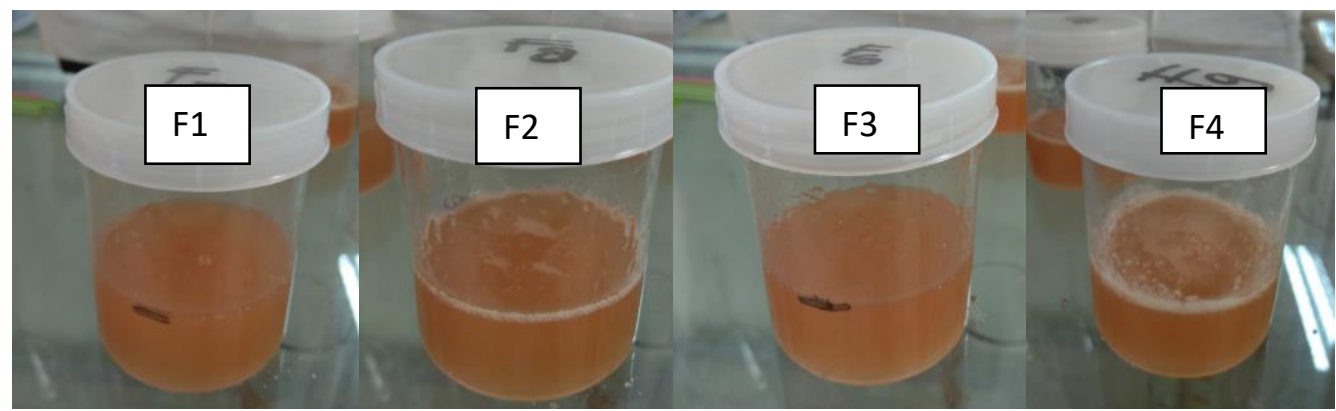

Gambar 2. Sediaan Hand sanitizer Ekstrak Biji Buah Alpukat

Ket :

$\mathrm{F} 1$ = Sediaan hand sanitizer dengan formulasi 1 (kadar etanol 0\%)

F2 = Sediaan hand sanitizer dengan formulasi 2 (kadar etanol 10\%)

F3 = Sediaan hand sanitizer dengan formulasi 3 (kadar etanol 20\%)

$\mathrm{F} 4=$ Sediaan hand sanitizer dengan formulasi 4 (kadar etanol 40\%) 
Sediaan hand sanitizer dengan bahan dasar ekstrak biji buah alpukat yang telah dibuat dilakukan beberapa pengujian diantaranya uji organoleptis, uji homogenitas, uji daya sebar, uji derajat keasaman $(\mathrm{pH})$, uji konsistensi dan uji viskositasserta uji zona hambat terhadap bakteri $E$. coli.

Tabel 2. Hasil Uji Fisik Sediaan Hand Sanitizer Ekstrak Biji Biji Alpukat

\begin{tabular}{clcccccc}
\hline No & \multicolumn{1}{c}{ Uji } & Satuan & F1 & F2 & F3 & F4 & K5 \\
\hline 1 & Viskositas & $\mathrm{KU}$ & 43,3 & 45 & 45,6 & 44 & 68,8 \\
2 & Daya Sebar & $\mathrm{cm}$ & 7,35 & 7,35 & 8,0 & 7,15 & 7,8 \\
3 & $\mathrm{pH}$ & - & 5,9 & 5,9 & 6,0 & 6,2 & 7 \\
4 & Zona Hambat & $\mathrm{mm}$ & 18 & 17 & 19,5 & 16 & 0 \\
\hline
\end{tabular}

Ket :

$\mathrm{F} 1$ = Sediaan hand sanitizer dengan formulasi 1 (kadar etanol 0\%)

F2 = Sediaan hand sanitizer dengan formulasi 2 (kadar etanol 10\%)

F3 = Sediaan hand sanitizer dengan formulasi 3 (kadar etanol 20\%)

F4 $=$ Sediaan hand sanitizer dengan formulasi 4 (kadar etanol 40\%)

F5 = Sediaan hand sanitizer yang beredar dipasaran

\section{Hasil Pengamatan Organoleptis}

Hasil uji organoleptis dilakukan merupakan hasil pengamatan langsung terhadap wujud atau bentuk fisik dari sediaan hand sanitizer yang telah dibuat dari ekstrak biji buah alpukat.Dari hasil pengamatan terlihat sediaan hand sanitizer dengan formulasi $1,2,3$ dan 4 yang diperoleh terlihat berupa cairan agak kental berwarna kuning kecoklatan dengan aroma khas dari ekstrak biji buah alpukat.Warna kuning kecoklatan berasal dari warna ekstrak yang digunakan. Sediaan hand sanitizer dengan formulasi 4 dimana kadar alkoholnya $40 \%$ tercium juga aroma alkoholnya.

\section{Hasil Pengamatan Homogenitas}

Homogenitas pada sediaan gel, diharapkan tidak terdapat butiran kasar dan homogeny.Persyaratan homogenitas tersebut guna bahan aktif dapat terdistribusi merata pada saat digunakan di kulit, apabila masih terdapat butiran kasar bisa mengiritasi kulit.

Dari hasil pengamatan homogenitas pada sediaan hand sanitizer ekstrak biji buah alpukat terlihat sudah homogen tetapi masih tampak ada bintik kecil. Pada pengamatan baik pada sedian hand sanitizer ekstrak biji buah alpukat formulasi 1 hingga 4 tampak sama. Hal itu mungkin dikarenakan CMC-nya belum melarut sempurna dalam sediaan hand sanitizer.

\section{Hasil Pengamatan Daya Sebar}

Pada sediaan gel guna dilakukan uji daya sebar untuk melihat kemampuan penyebaran gel saat dioleskan pada kulit. Hal ini berhubungan dengan transfer bahan aktif pada daerah sasaran dalam dosis yang tepat, kemudahan pemakaian, tekanan yang dibutuhkan saat dikeluarkan dari kemasan dan penerimaan oleh konsumen. Persyaratan daya sebar gel adalah 5$7 \mathrm{~cm}$. Pada hasil pengamatan uji daya sebar sediaan hand sanitizer ekstrak didapatkan berkisar dari 7,15 sampai dengan $8 \mathrm{~cm}$. Sedangkan pada hand sanitizer kontrol positif, sebagai pembanding daya sebarnya $7,8 \mathrm{~cm}$. Sediaan dengan formulasi 4 , memiliki nilai daya sebar yang paling mendekati nilai $7 \mathrm{~cm}$ yakni $7,15 \mathrm{~cm}$.

\section{Uji Derajat keasaman (pH)}

Derajat keasaman juga memiliki peranan yang cukup penting, dimana sebagai parameter fisikokimia yang harus diukur pada sediaan topikal. Ini dikarenakan akan mempengaruhi efektivitas zat aktif, kestabilan zat aktif dan sediaan, serta kenyamanan sediaan saat digunakan pada kulit. Sediaan yang terlalu basa $(\mathrm{pH}>7)$ akan menimbulkan kulit yang bersisik 
sedangkan bila terlalu asam $(\mathrm{pH}<7)$ dapat menyebabkan iritasi kulit.

Persyaratan derajat keasaman untuk sediaan topikal berkisar pada $\mathrm{pH}$ 4-8. Dari hasil pengukuran $\mathrm{pH}$ sediaan hand sanitizer ekstrak menggunakan alat $\mathrm{pH}$ meter, didapatkan nilainya berkisar 5,9 sampai dengan 6,2, sehingga ini masih memenuhi syarat $u$ sediaan topikal.

\section{Hasil Uji Konsistensi}

Tujuan dilakukan uji konsistensi guna untuk melihat terjadi atau tidak pemisahan fase pada formula sediaan hand sanitizer, yang nantinya mengindikasikan kestabilan dari sediaan hand sanitizer. Proses terjadinya pemisahan fase terjadi bila cairan sediaan gel keluar dan berkumpul di permukaan sehingga akan terlihat lapisan cairan di permukaan sediaan akibat terjadi penurunan konsentrasi polimer.

Pada hasil pengamatan sediaan hand sanitizer ekstrak biji buah alpukat, dari hari pertama pembuatan dan hingga 7 hari tidak terbentuk pemisahan fase, artinya konsistensi sediaan hand sanitizer ekstrak masih stabil. Tetapi pada hasil pengamatan uji konsistensi sediaan hand sanitizer ekstrak dengan menggunakan sentrifuge, terbentuk pemisahan fase pada permukaan sediaan hand sanitizer ekstrak baik formulasi 1-5 dimana ada cairan berwarna coklat yang lebih gelap di atas permukaan hand sanitizer ekstrak. Sedangkan pada hand sanitizer kontrol positif tidak terbentuk pemisahan fase. Dengan begitu sediaan hand sanitizer ekstrak dengan formulasi 1-4 dalam penyimpanan yang lebih lama konsistensinya belum stabil bila dibandingkan dengan yang kontrol positif

\section{Hasil Uji Viskositas}

Pengukuran viskositas gel menggunakan alat viscometer Brookfield dan persyaratan viskositas gel berkisar 20000-40000 cp. Dari hasil pengamatan nilai viskositas sediaan hand sanitizer ekstrak biji buah alpukat formulasi 1-4 maupun yang kontrol positif berkisar 164 hingga $533 \mathrm{cp}$, dengan begitu terlihat bahwa masih jauh sekali dari rentang nilai viskositas gel yang seharusnya.

\section{Uji Zona Hambat terhadap Bakteri E.coli}

Hasil dari uji aktivitas sediaan hand sanitizer ekstrak biji buah alpukat terhadap bakteri E.coli, terlihat adannya zona hambat sebesar 16-19,5 mm. Sedangkan pada sediaan hand sanitizer sebagai kontrol positif tidak terbentuk zona hambat sama sekali. Sediaan hand sanitizer ekstrak dengan formulasi 3 (F3) kandungan alkohol 96\% sebanyak $20 \%$, memiliki diameter zona hambat yang paling besar yakni 19,5 mm.

\section{PEMBAHASAN}

Hasil uji aktivitas antibakteri terhadap bakteri E.coli pada sediaan hand sanitizer ekstrak biji buah alpukat, terdapat zona hambat baik dari sediaan hand sanitizer formulasi 1 hingga 4 . Rerata diameter zona hambat hand sanitizer berbahan aktif ekstrak biji alpukat berkisar 16-19,5 mm, berdasarkan tabel klasifikasi respon hambatan pertumbuhan bakteri termasuk kategori kuat (11-19 mm). Hasil uji fitokimia pada ekstrak biji alpukat memiliki kandungan senyawa flavonoid, alkaloid, saponin, dan tanin (Benget, 2016). Diduga adanya zona hambat tersebut karena kandungan metabolit sekunder pada ekstrak biji buah alpukat memiliki aktifitas antimikroba yang mampu merusak sel dengan cara menghambat pembentukan dinding dan membran sel yang menyebabkan terganggunya permeabilitas sel atau mungkin menghambat sintesis protein dan asam nukleat sehingga sel tidak dapat lagi melangsungkan hidupnya karena proses utama dalam hidupnya sudah dirusak oleh ekstrak tersebut (Berdy, 2005). Ekstrak biji alpukat dapat bersifat bakteriosid terhadap Streptococcus mutans, dan semakin besar konsentrasi ekstrak biji alpukat maka semakin besar pula daya hambatnya (Thalib dan Nahar, 2018). 


\section{KESIMPULAN}

Sediaan hand sanitizer dengan bahan dasar ekstrak biji buah alpukat formulasi 3 (F3) dengan kandungan alkohol $96 \%$ sebanyak $20 \%$ b/v mempunyai nilai diameter zona hambat yang paling besar terhadap bakteri $E$. coli dan memiliki karakteristik fisik sediaan hand sanitizer yang lebih baik.

\section{SARAN}

Masih perlu dilakukan penelitian lebih lanjut terkait optimasi formulasi sediaan gel hand sanitizer berbahan dasar ekstrak biji alpukat dan pengujian terhadap mikroba lainnya.

\section{DAFTAR PUSTAKA}

Anggraeny, Dyta. Rumengan, Inneke F. M. Djarkasi, Gregoria S. S. Suptijah, Pipih. (2017). Aktivitas Antioksidan Ekstrak Biji Alpukat (Persea americana Mill.) Yang Disalut Dengan Nanokitosan. J. Ilmu dan Teknologi Pangan 5(2): 6-10.

Ansel, H.C. (2011). Pengantar Bentuk Sediaan Farmasi. Jakarta: UI-Press.

Benget, Vivekananda V. (2016). Uji aktivitas antibakteri ekstrak biji alpukat (Persea americana Mill.) Terhadap Bacillus cereus dan Vibrio cholerae dengan variasi pengekstrak. [Skripsi]. Yogyakarta: Universitas Atma Jaya Yogyakarta.

Berdy J. (2005). Bioactive microbial metabolites. Review Article. J Antibiot 58 (1): 1-26.

Departemen Kesehatan RI. (2017). Farmakope Herbal. Jakarta: Depkes RI.

Garg, A., Aggarwal, D., Garg, S., and Sigla, A.K. (2002). Spreading of Semisolid Formulation: An Update Pharmaceutical Technology 26(9): 84- 102.

Leite, J.J.G., Brito, E.H.S., Cordeiro, R.A., Brilhante, R.S.N., Sidrim, J.J.C., Bertini, L.M., Morais, S.M.D., Rocha, M.F.G. (2009). Chemical Composition, Toxicity and Larvacidal and Antifungal Activities of Persea americana
(Avocado) Seed Extract. Revista da Sociedadae Brasileira de Medicina Tropical 2(42): 110113.

Ozolua RI, Anaka ON, Okpo SO, Idogun SE. (2009). Acute and sub-acute toxicological assessment of the aqueous seed extract of persea americana mill (lauraceae) in rats. Afr J Trad CAM 6(4): 573-8.

Riadi, Selamat. (2014). Aktivitas Antimikroba Ekstrak Biji Alpukat (Persea Americana Mill) Terhadap Beberapa Mikroba Pathogen Secara In Vitro. [Tesis]. Medan: Universitas Sumatera Utara.

Suhendra, Abraham T. Awaloei, Henoch. Wuisan, Jane. (2016). Uji efek ekstrak biji alpukat (Persea americana Mill.) terhadap kadar kolesterol total pada tikus wistar (Rattus norvegicus). Jurnal e-Biomedik (eBm) 4(1).

Thalib, Bahruddin \& Nahar, Citra Lestari. (2018). Efektivitas Antibakteri Ekstrak Biji Alpukat (Persea americana Mill.) terhadap Streptococcus mutans. Makassar Dent J volume 7(1):26-29.

World Health Organization. (2009). Guidelines On Hand Hygiene In Health Care: First Global Patient Safety Challenge Clean Care Is Safer Care. Geneva: World Health Organization. 